\title{
Basosquamous cell carcinoma
}

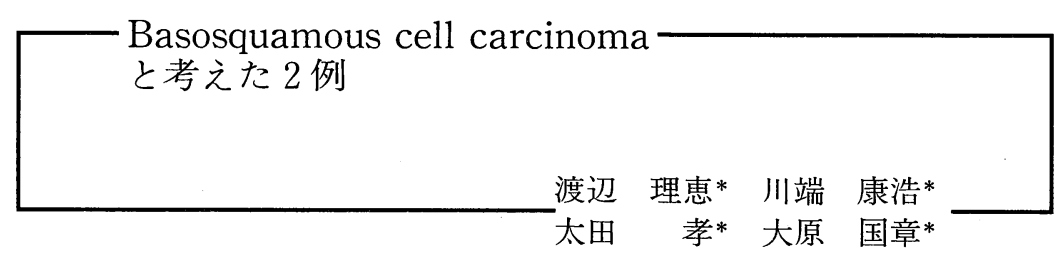

\section{Summary}

我々は BCEの組織に squamous differentiation を示す basosquamous cell carcinoma の症例を 2 例報告した。症例 1,62 歳男。左鼻翼部の黒色腫瘤を切除, 病理組織像は表皮 より連続性に異型性を示す squamoid cell の浸潤増殖像を認め, 漸時 basaloid cell に移 行，周辺部では典型的 BCE の像をとる。症例 2,63 歳男。右耳介部の色素斑，病理組織像 は中心に潰瘍を挟み, basaloid cell と squamoid cell の增殖像を認める, 周辺部に BCE 有 $\eta$ 。2 例とも切除後 9 力月, 再発, 転移無し。

\section{緒}

\section{言}

BCEの組織中に squamous differentiation を認め, 臨床的悪性度の高いことを特徵とする basosquamous cell carcinoma (以下 BSCC) の報告例が近年増えて来ている。今回我々は BSCC と考えた 2 例を経験したので報告する。

\section{症例}

症例 $1: 62$ 歳, 男性

家族歴：特記すべきことなし。

既往歴：特記すべきことなし。

現病歴： 2 年前より左鼻翼部に小腫瘤出現 し，漸次増大してきた。

現 症：左鼻翼部に $11 \times 8 \mathrm{~mm}$ の腫瘤があ $\eta$, 辺縁は常色から黒色の小結節が集簇, 堤防

* Rie WATANABE, Yasuhiro KAWABATA, Takashi OTA, Kuniaki OHARA, 虎の門病院皮 膚科
状に隆起し, 中央に潰瘍形成を認める（図 1)。 自覚症状なし。

治療および経過：臨床的に基底細胞上皮腫と 診断し, 全身麻酔下に全摘術施行し, nasolabial flap にて再建した。術後 9 力月の現在再発転移 の兆候は認めていない。

病理組織学的所見：腫瘍細胞は表皮より下方 に向かって連続性に不規則な浸潤性増殖像を呈 し，真皮下層まで達している。腫瘍最外層では 好塩基性の細胞集塊が見られ，周辺には炎症性 細胞浸潤が見られる。表皮は一部に過角化を示 す(図 2)。表皮と連続する部分では浸潤細胞は 好酸性，角化傾向のあるやや大型の squamoid cell であり，真皮に向かい不規則な増殖像をと る。核には大小不同があり，核分裂像も見られ る(図 3 )。その squamoid cell は下方に向かj に従い, 徐々にやや小型で淡い好塩基性の細胞 へと移行し, 索状〜巣状配列を取り増殖するが, ここでは辺縁部の栅状配列は見られない（図 4 )。この細胞を一応 intermediate cell とする。 その外層では細胞はさらに小型の basaloid cell 
となり, 巣状に増殖, 辺縁の細胞は栅状配列を とり, 典型的な充実型の基底細胞上皮腫像を示 している(図 5 )。

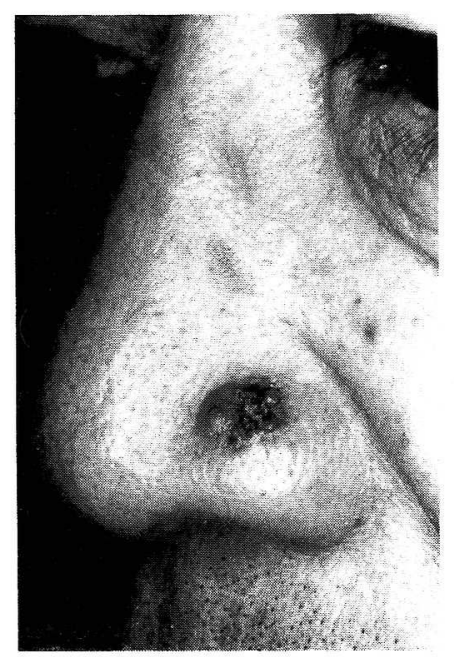

図 1.症例 1 臨床像

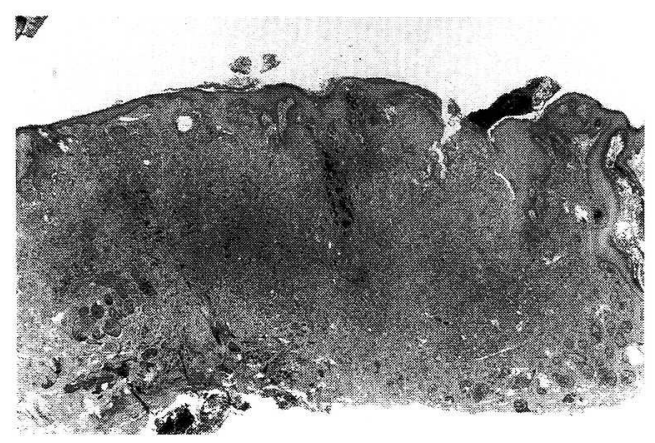

図 2. 症例 1 組織像・全体像

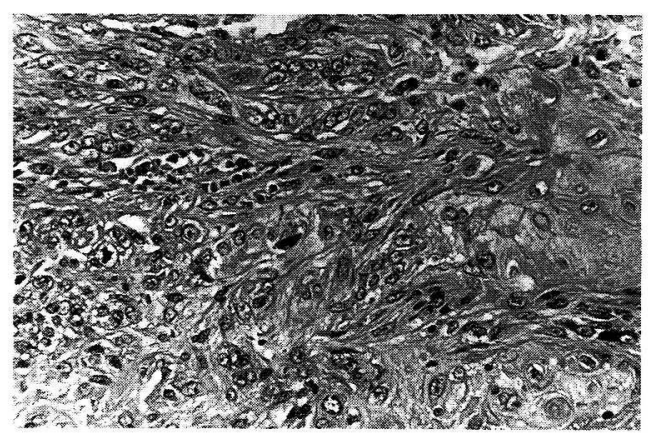

図 3.症例 1 組織像

異型な Squamoid cell の浸潤增殖像

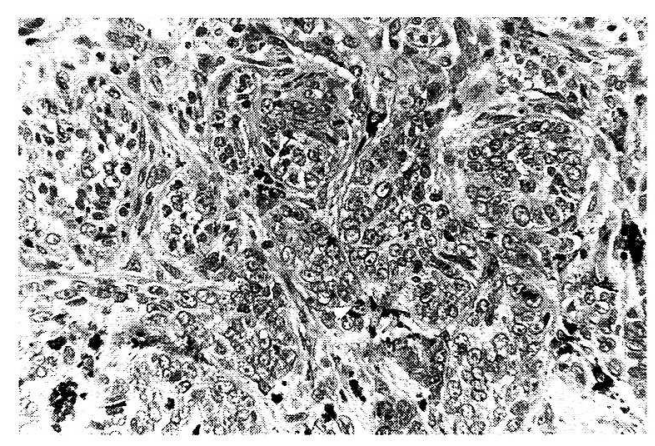

図 4.症例 1 組織像

Intermediate cell 辺縁の細胞の栅状配列は見 られない

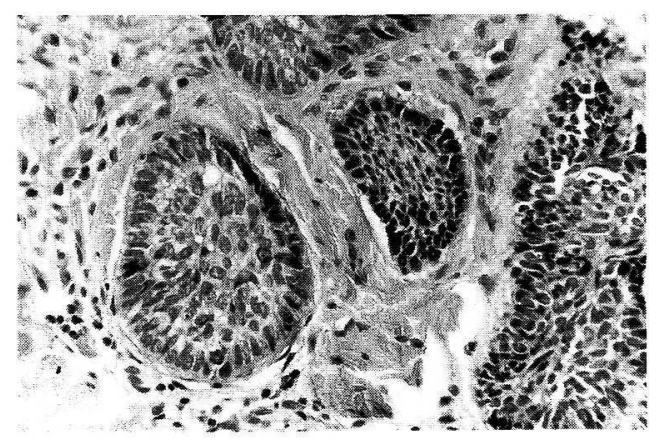

図 5. 症例 1 組織像 充実型基底細胞上皮腪像を示す

症例 $2: 63$ 歳, 男性

家族歴：特記すべきことなし。

既往歴：胃癌, 笃結石, 不整脈

現病歴：初診 2 力月前に右耳の黒色斑に気付 <。

現 症：右耳介上部に $9 \times 14 \mathrm{~mm}$ の淡紅色 斑があり, 辺縁に一部黒色斑を認め, 中心はび らんを呈する(図6)。自党症状なし。

治療および経過：臨床的に基底細胞上皮腫と 診断し, 切除, 遊離植皮術を施行した。術後 9 力 月の現在, 再発転移の兆候は認めていない。

病理組織学的所見：病変は水平方向に広く存 在し, 充実型, 表在型の基底細胞上皮腫が各々 間隔を置いて存在している(図 7 )。病変中心付 
近では（図 8 ）中央に潰瘍形成があり，その左 側では表皮より連続性に有棘細胞の真皮への不 規則な浸潤増殖像を認める。細胞は比較的大型, 好酸性に富み，一部角化を示す squamoid cell である。細胞異型も軽度ながら認めるが核分裂 像は見られない。真皮には出血および炎症性細 胞浸潤を認める（図 9）。

潰瘍の左側には比較的小型でやや好塩基性の basaloid cell の集塊が索状〜巣状に浸潤増殖 しており,この部分は基底細胞上皮腫と考之た。 この basaloid cell は中心部, 潰瘍付近で前述の squamoid cell と混在, 移行している（図10）。

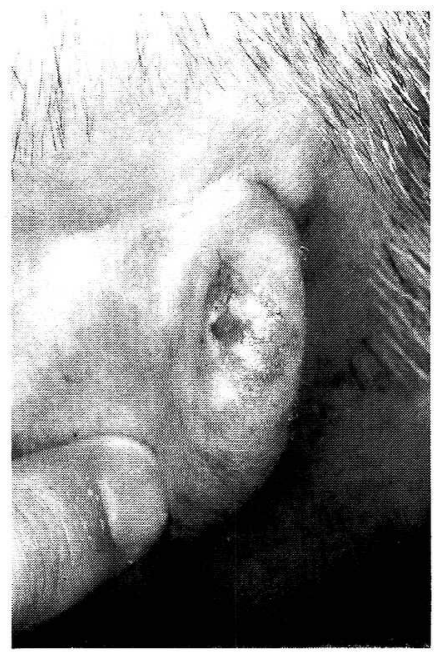

図 6.症例 2 臨床像

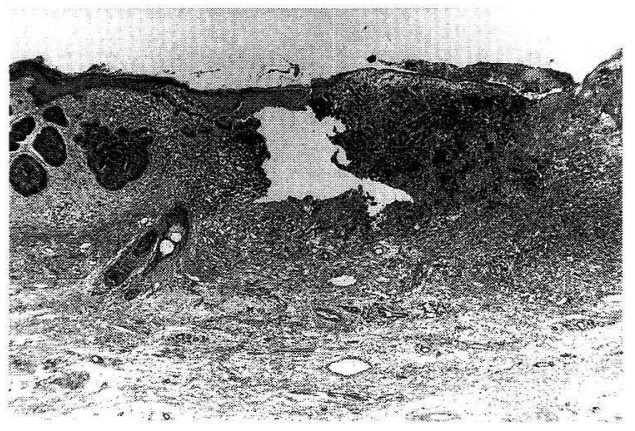

図 7 . 症例 2 組織像・弱拡大像

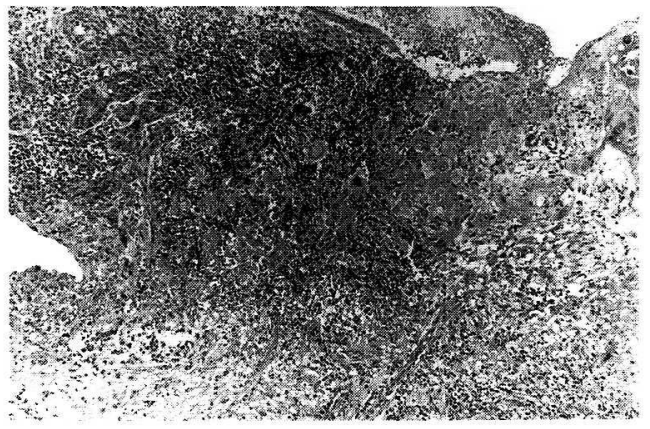

図 8.症例 2 組織像

中心付近の中拡大像

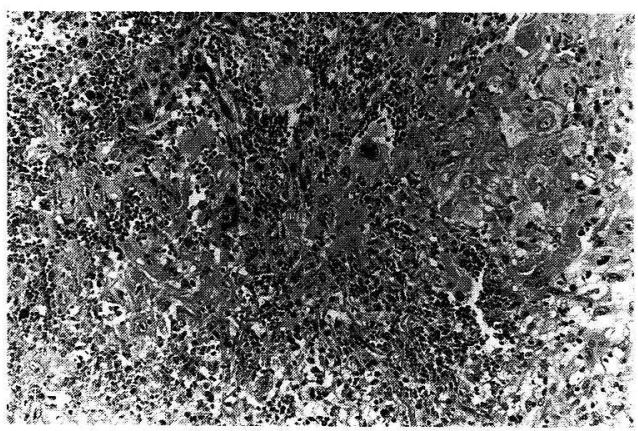

図 9.症例 2 組織像

Squamoid cell の胞巣，出血も混じる

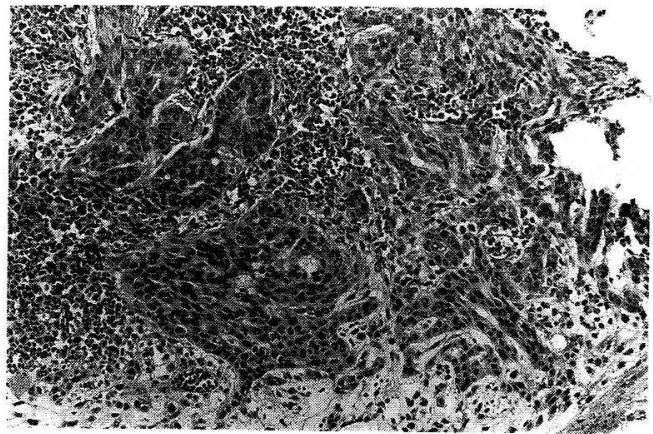

図10.症例 2 組織像

Basaloid cell の胞巣 


\section{考察}

Basosquamous cell carcinoma の存在には 未だ議論の残るところである。1922年 Darier ら ${ }^{1)} \mathrm{BCE}$ と SCCの中間型を示す腫瘍を報 告，1928年 Montgomery ${ }^{2)}$ はれを Basal squamous cell epithelioma と名付けその臨床 的悪性度の高いことを報告した。1957年，Bruston $ら^{3}$ はこれを squamous differentiationを 示す $\mathrm{BCE}$ と定義した。その後これを支持する 報告4)も見られたが，この疾患に封する反対意 見も多く,久しくこの概念は省みられなかった。 しかし近年 BSCCに関する報告が相次ぎ，この 臨床形態，組織学的所見，予後等が次第に明ら かになり，漸く 1 つの疾患単位として認められ つつある。

Borel ら ${ }^{5)}$ は，BSCC35例を集計し報告してい るが，それによると発生年齢は60歳代に多く， 男女比は圧倒的に男性に多い。発生部位は顔面 が主で特に耳と鼻に多い傾向がある。また臨床 像は潰瘍形成を見ることが特徵という。その臨 床的悪性度は $\mathrm{BCE}$ と比較し有意に高く，局所 再発は $45.7 \%$ ，転移は $8.6 \%$ に認め，臨床的に BCE とは明らかに異なる entityを形成してい る。これにより治療においてはSCC と同等の 取扱いが必要とされる。そして転移巣において も原発巣と同様の basaloid cell, intermediate cell, squamoid cell を認める報告 ${ }^{6,7)}$ がなされて 扮り，BSCC という疾患概念の根拠ともなって いる。本症第 1 例は病変中心部から表皮より連 続性に squamoid cell, intermediate cell, basaloid cell と漸次移行しつつ浸潤増殖する像 を呈し，辺縁部では典型的 BCEを認めた。しか し,病変の主体は squamoid intermediate cell であり，この部分では細胞の異型性や，核分裂 像等の悪性所見もみられ，BSCC に相当すると 考えた。
第 2 例は basaloid cell 部分と squamoid cell 部分が潰瘍を中心に左右に見られ，中心付近で は両者の混在像を呈する症例である。この症例 では細胞異型は軽度で pseudo carcinomatous hyperplasia $(\mathrm{PCH})$ との異同が問題となる。 $\mathrm{PCH}$ は表 1 に示した疾患に伴ってみられ， BCEにも起こり得る。しかし $\mathrm{PCH}$ では表皮肥 厚, 表皮索延長, squamous eddie 等は認めるも, 細胞の異型性をみることは無く，この点でSCC と鑑別できる。本例には異型性も軽度ながら存 在し，また squamoid cell 部分が basaloid cell を超え下方に増殖していること，両者が中央で 密に混在していることなどの発育形式より，第 2 例も BSCC と考えた。また 2 例とも角化型 BCE とは明らかに鑑別可能である。

本症例は 2 例とも切除後 9 力月の現在, 再発, 転移の兆候は認めないが今後とも注意深く経過 観察すべきと考える。

表 1. Pseudo carcinomatous hyperplasia をきたす疾患

\begin{tabular}{|c|c|}
\hline \multirow{5}{*}{1} & In chronic proliferative inflammatory process \\
\hline & Bromoderma \\
\hline & Blastomycosis \\
\hline & Hidradenitis suppurativa \\
\hline & Blastomycosis-like pyoderma \\
\hline \multirow{8}{*}{2} & At the edge of chronic ulcers \\
\hline & Burns \\
\hline & Pyoderma gangrenosum \\
\hline & Status dermatitis \\
\hline & Lupus vulgaris \\
\hline & Scrofuloderma \\
\hline & Gumma \\
\hline & Basal cell epithelioma \\
\hline 3 & Granular cell tumor \\
\hline
\end{tabular}




\section{文献}

1) Darier, J. : Br. J. Derm. Syph. , 34, 145-149, 1922.

2) Montgomery, H.: Arch. Dermatol., 18, 50-73, 1928.

3) Burston, J. , Clay, R.D. : J. Clin. Pathol. , 12, 73 $-79,1959$.
4) Lund, H.Z. : Tumor of the Skin, Armed Forces Inst. Pathology. Washington, p. 234-235, 1957.

5) Borel, D.M. : Arch. Pathol., 95 : 293-297, 1973.

6) Lopes De Faria. J., Nunes, P.H.F. : Histopathology, 12, 85-94, 1988.

7) Farmer, E.R., Helwig, E.B. : Cancer, 46, 748 $-757,1980$. 